\title{
PENGARUH PEMULSAAN JERAMI PADI DAN SISTEM OLAH TANAH TERHADAP PERTUMBUHAN DAN HASIL TANAMAN KEDELAI (Glycine max L. merril) NON-ORGANIK
}

\author{
Lutfy Ditya Cahyanti \\ Agroteknologi Universitas Darussalam Gontor \\ Email : lutfyditya@unida.gontor.ac.id
}

Diterima 20 Desember 2016, Disetujui 8 Maret 2017

\begin{abstract}
One of the factors that decrease the production of the soybean crop is the low level of soil fertility. Soil fertility can be improved with the use of mulch combined with proper tillage. This Research is needed to determine the dose and the right soil processing combined with optimal doses of straw mulch to improve the growth and yield of soybean.This research conducted wit Split Plot Design with three replication, with soil tillage as main plot and rice straw mulch as sub plot. Soil tillage arranged with 3 level, O1: maximum soil tillage $\mathrm{O} 2$ : minimum soil tillage and O3: without soil tillage. Rice straw mulch arranged with 4 level, $M_{0}$ : without rice straw mulch (control), $M_{1}$ : rice straw mulch 2 ton/ha, $M_{2}$ : rice straw mulch 4 ton/ha and $\mathrm{M}_{3}$ : rice straw mulch 6 ton/ha. The results showed there were no significant interactions and influences between pemulsaaan treatment combined with tillage on the growth and yield of soybean.
\end{abstract}

Key words: Soybean, Rice Straw Mulch dan Soil Tillage.

\section{PENDAHULUAN}

Kedelai merupakan salah satu komoditi pangan utama di Indonesia setelah padi dan jagung. Kedelai menjadi bahan pangan utama sumber protein nabati bagi masyarakat Indonesia. Kebutuhan kedelai dari tahun ke tahun terus meningkat. Kedelai banyak digunakan sebagai bahan makanan seperti tempe, tahu, tauco, maupun susu kedelai, sehingga kebutuhan akan kedelai terus meningkat. Saat ini pasokan kedelai dalam negeri tidak bisa mencukupi kebutuhan masyarakat.

Data Badan Pusat Statistik menunjukkan bahwa produksi kedelai di Indonesia pada tahun 2013 mencapai 779.992 ton, dengan konsumsi perkapita rata-rata 9,42 $\mathrm{kg} /$ tahun. Produktifitas rata-rata kedelai nasional juga rendah, tahun 2013 mencapai $14,16 \mathrm{ku} / \mathrm{ha}$ atau 1,4 ton/ha sedangkan potensi hasil ditingkat penelitian dan percobaan mencapai 2 ton (BPS $\left.{ }^{\mathrm{a}}, 2015\right)$. Pemenuhan kebutuhan kedelai dalam negeri, kekurangan kedelai tersebut harus dipenuhi dengan impor. Usaha-usaha untuk mengurangi tingginya angka impor kedelai, perlu dilakukan peningkatkan produksi kedelai dalam negeri.
Kabupaten Ponorogo sendiri, berdasarkan data BPS tahun 2013, produksi kedelai mencapai 160.233 kuintal dengan produktivitas 16,78 kuintal/ha (BPS $\left.{ }^{\mathrm{b}}, 2015\right)$. Salah satu faktor yang menurunkan produksi tanaman kedelai dan juga rendahnya produktivitas tanaman kedelai adalah rendahnya tingkat kesuburan tanah. Kesuburan tanah diantaranya dapat ditingkatkan dengan penggunaan mulsa yang dikombinasikan dengan pengolahan tanah yang tepat.

Mulsa adalah bahan untuk menutup tanah sehingga kelembaban dan suhu tanah sebagai media tanaman terjaga kestabilannya. Berdasarkan sumber bahan dan cara pembuatannya, mulsa dapat dibedakan menjadi dua kelompok, yaitu mulsa organik dan mulsa anorganik (kimia sintetis). Mulsa organik ialah mulsa yang bahannya berasal dari tanaman atau sisa tanaman pertanian (Akbar, 2014). Mulsa organik yang sering diberikan pada lahan pertanian misalnya jerami padi. Jerami padi ini mempunyai banyak fungsi, khususnya dalam rangka mempertahankan produktivitas tanah dan juga berfungsi sebagai pengendali gulma. 
pengendali gulma, mulsa efektif untuk meningkatkan bahan organik sehingga dapat memperbaiki sifat fisik tanah, kimia tanah dan biologi tanah. Sisa tanaman dapat menarik binatang tanah karena kelembaban tanah yang stabil dan tersedianya bahan organik sebagai makanannya, hal tersebut berpengaruh pada aerasi dan kemampuan tanah dalam menyerap air akan lebih baik. Besar kecilnya pengaruh yang ditimbulkan akibat pemulsaan tersebut akan bergantung juga pada tingkat ketebalan dan bahan dari mulsa itu sendiri (Akbar, 2014). Diperlukan pengaturan pemberian mulsa seperti jenis bahan dan ketebalan mulsa (dosis mulsa) agar pemberian mulsa tersebut tepat.

$$
\text { Pengolahan tanah merupakan }
$$

kegiatan pembalikan, pemotongan, penghancuran, dan perataan tanah. Tujuan dari pengolahan tanah adalah untuk memperbaiki kondisi tanah untuk penetrasi akar, infiltrasi air dan peredaran udara (aerasi) tanah, menyiapkan tanah untuk irigasi permukaan dan pengendalian hama serta menghilangkan sisa-sisa tanaman yang mengganggu pertumbuhan tanaman (Prasetyp, 2014). Pengolahan tanah sangat mempengaruhi sifat tanah yang dihasilkan. Sifat tanah yang baik mencerminkan kondisi tanah yang sesuai untuk pertumbuhan tanaman. Pengolahan tanah yang tepat memiliki beberapa keuntungan, diantaranya ialah untuk menekan pertumbuhan gulma sehingga ketersediaan unsur hara meningkat, memperbaiki aerasi tanah serta membersihkan lahan, sehingga akan meningkatkan produktifitas lahan.

Tujuan penelitian adalah mengetahui dosis erami padi yang dibutuhkan sebagai mulsa, karena dosis jerami yang diperlukan tergantung kepada kondisi cuaca, topografi, air irigasi, dan kualitas tanah sehingga diperlukan penelitian untuk menentukan dosis dan pengolahan tanah yang tepat dikombinasikan dengan dosis mulsa jerami optimal untuk meningkatkan pertumbuhan dan hasil tanaman kedelai.

\section{METODE}

Penelitian dilaksanakan di lahan percobaan program studi Agroteknoogi
Universitas Darussalam Gontor dengan rancangan yang digunakan dalam penelitian ini ialah Rancangan Petak Terbagi. Perlakuan diulang sebanyak 3 kali. Perlakuan pengolahan tanah ditempatkan sebagai petak pertama (O) yang terdiri dari 3 taraf, dengan kombinasi perlakuan seperti pada Tabel 1 .

O1: Olah tanah sempurna

O2: Olah tanah minimum

O3: Tanpa Olah tanah

Perlakuan Ketebalan mulsa jerami padi dengan beberapa level sebagai anak petak terdiri dari 4 level, adalah:

M0: Tanpa jerami padi (kontrol)

M1: Jerami padi 2 ton/ha

M2: Jerami padi 4 ton/ha

M3: Jerami padi 6 ton/ha

Tabel 1. Kombinasi perlakuan pengolahan tanah dan ketebalan mulsa jerami padi

\begin{tabular}{ccccc}
\hline \multirow{2}{*}{$\begin{array}{c}\text { Pengolahan } \\
\text { tanah }\end{array}$} & \multicolumn{4}{c}{ Mulsa Jerami } \\
\cline { 2 - 5 } & $\mathrm{M} 0$ & $\mathrm{M} 1$ & $\mathrm{M} 2$ & $\mathrm{M} 3$ \\
\hline $\mathrm{O} 1$ & $\mathrm{M} 0 \mathrm{O} 1$ & $\mathrm{M} 1 \mathrm{O} 1$ & $\mathrm{M} 2 \mathrm{O} 1$ & $\mathrm{M} 3 \mathrm{O} 1$ \\
$\mathrm{O} 2$ & $\mathrm{M} 0 \mathrm{O} 2$ & $\mathrm{M} 1 \mathrm{O} 2$ & $\mathrm{M} 2 \mathrm{O} 2$ & $\mathrm{M} 3 \mathrm{O} 2$ \\
$\mathrm{O} 3$ & $\mathrm{M} 0 \mathrm{O} 3$ & $\mathrm{M} 1 \mathrm{O} 3$ & $\mathrm{M} 2 \mathrm{O} 3$ & $\mathrm{M} 3 \mathrm{O}$ \\
\hline
\end{tabular}

Parameter yang diamati meliputi tinggi tanaman, jumlah daun, jumlah polong, jumlah polong isi dan bobot biji pertanaman.

\section{HASIL DAN PEMBAHASAN}

sil pengamatan menunjukkan bahawa perlakuan pemulsaan dikombinasikan dengan perlakuan pengolahan tanah belum terdapat interaksi dan belum menunjukkan pertumbuhan dan hasil tanaman kedelai yang berbeda nyata. Pertumbuhan tanaman ialah proses yang terjadi dalam kehidupan tanaman dengan habitatnya yang dapat didekati dengan semua pengamatan peubah-peubah pertumbuhan tanaman seperti tinggi tanaman, jumlah daun diameter batang, luas daun dan bobot kering tanaman dan lainnya (Tabel 2). 
Pengaruh Pemulsaan Jerami Padi dan Sistem Olah Tanah terhadap Kedelai

Tabel 2. Jumlah daun tanaman kedelai pada berbagai umur tanaman dengan berbagai perlakuan

\begin{tabular}{|c|c|c|c|c|c|c|c|c|c|c|c|c|}
\hline \multirow{3}{*}{ Pemulsaan } & \multicolumn{12}{|c|}{ OLAH TANAH } \\
\hline & \multicolumn{4}{|c|}{$\begin{array}{c}\text { Maksimal } \\
\text { Umur Pengamatan (hst) }\end{array}$} & \multicolumn{4}{|c|}{$\begin{array}{c}\text { Minimal } \\
\text { Umur Pengamatan (hst) }\end{array}$} & \multicolumn{4}{|c|}{$\begin{array}{c}\text { Tanpa olah tanah } \\
\text { Umur Pengamatan (hst) }\end{array}$} \\
\hline & 14 & 21 & 28 & 35 & 14 & 21 & 28 & 35 & 14 & 21 & 28 & 35 \\
\hline $\begin{array}{c}0 \mathrm{Kg} \\
\text { MULSA }\end{array}$ & 3,3 tn & $\begin{array}{c}11,2 \\
\text { tn }\end{array}$ & $17 \mathrm{tn}$ & $\begin{array}{c}28,4 \\
\text { tn }\end{array}$ & 4,0 tn & $\begin{array}{c}11,4 \\
\text { tn }\end{array}$ & $\begin{array}{l}17,6 \\
\text { tn }\end{array}$ & $\begin{array}{c}36,6 \\
\text { tn }\end{array}$ & 4,0 tn & $\begin{array}{c}11,4 \\
\text { tn }\end{array}$ & $\begin{array}{c}17,6 \\
\text { tn }\end{array}$ & $\begin{array}{c}32,4 \\
\text { tn }\end{array}$ \\
\hline $\begin{array}{c}2 \mathrm{Kg} \\
\text { MULSA }\end{array}$ & 4,3 tn & $\begin{array}{l}10,8 \\
\text { tn }\end{array}$ & 17, tn & $\begin{array}{l}30,4 \\
\text { tn }\end{array}$ & $4,0 \mathrm{tn}$ & 9,8 tn & $\begin{array}{l}16,0 \\
\text { tn }\end{array}$ & $\begin{array}{c}21,2 \\
\text { tn }\end{array}$ & 3,0 tn & 9,8 tn & $\begin{array}{l}18,4 \\
\text { tn }\end{array}$ & $\begin{array}{c}29,4 \\
\text { tn }\end{array}$ \\
\hline $\begin{array}{l}4 \mathrm{Kg} \\
\text { MULSA }\end{array}$ & $4,3 \mathrm{tn}$ & 9,4 tn & $\begin{array}{l}16,8 \\
\operatorname{tn}\end{array}$ & $\begin{array}{c}28,4 \\
\text { tn }\end{array}$ & 3,3 tn & $\begin{array}{c}10,4 \\
\operatorname{tn}\end{array}$ & $\begin{array}{l}16,2 \\
\text { tn }\end{array}$ & $\begin{array}{c}27,8 \\
\text { tn }\end{array}$ & $4,0 \mathrm{tn}$ & $\begin{array}{l}10,6 \\
\text { tn }\end{array}$ & $\begin{array}{l}16,4 \\
\text { tn }\end{array}$ & $\begin{array}{l}24,2 \\
\text { tn }\end{array}$ \\
\hline $\begin{array}{c}6 \mathrm{Kg} \\
\text { MULSA }\end{array}$ & $3,2 \mathrm{tn}$ & 9,6 tn & $\begin{array}{l}14,6 \\
\text { tn }\end{array}$ & $\begin{array}{l}22,6 \\
\text { tn }\end{array}$ & 4,3 tn & $\begin{array}{l}10,4 \\
\text { tn }\end{array}$ & $16 \mathrm{tn}$ & $\begin{array}{l}28,8 \\
\text { tn }\end{array}$ & $4,3 \mathrm{tn}$ & 9,0 tn & $\begin{array}{c}14,4 \\
\text { tn }\end{array}$ & $\begin{array}{c}20,3 \\
\text { tn }\end{array}$ \\
\hline
\end{tabular}

tn : tidak nyata dengan BNT 5\% dan tidak ada interaksi antara perlakuan olah tanah dan pemulsaan

Adapun hasil data Tabel 2 seperti pada grafik Gambar 1

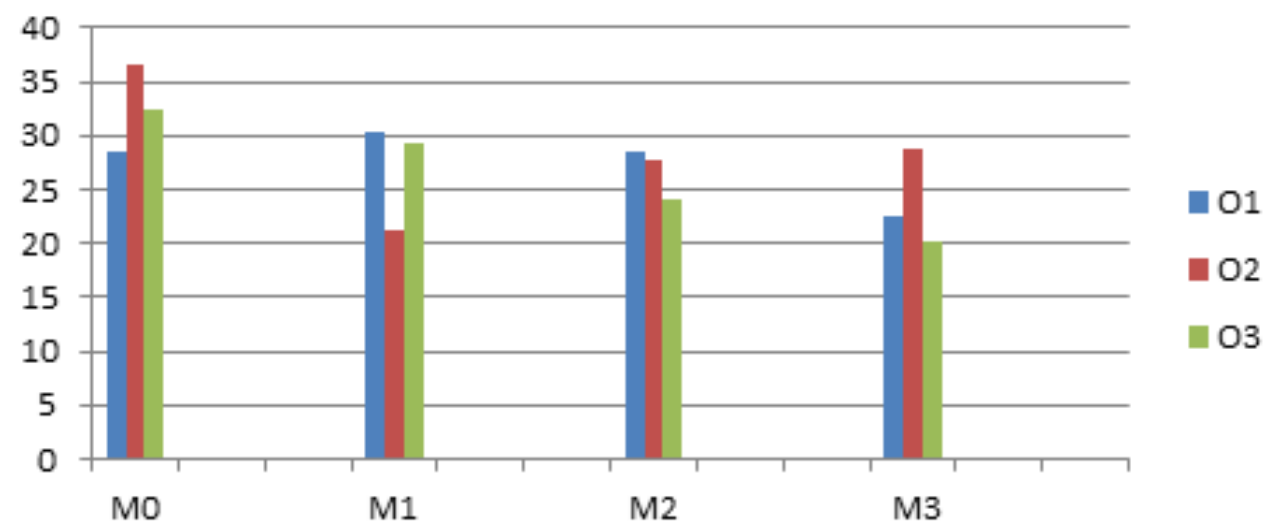

Gambar 1. Grafik jumah daun tanaman kedelai pada umur 35 hst dengan berbagai perlakuan Keterangan : O1: Olah tanah sempurna, O2: Olah tanah minimum, O3: Tanpa Olah tanah, M0: Tanpa jerami padi (kontrol), M1: Jerami padi 2 ton/ha, M2: Jerami padi 4 ton/ha, M3: Jerami padi 6 ton/ha

Tabel 3. Tinggi tanaman kedelai pada berbagai umur tanaman dengan berbagai perlakuan $(\mathrm{cm})$

\begin{tabular}{|c|c|c|c|c|c|c|c|c|c|c|c|c|}
\hline \multirow{3}{*}{ Pemulsaan } & \multicolumn{12}{|c|}{ OLAH TANAH } \\
\hline & \multicolumn{4}{|c|}{$\begin{array}{c}\text { Maksimal } \\
\text { Umur Pengamatan (hst) }\end{array}$} & \multicolumn{4}{|c|}{$\begin{array}{c}\text { Minimal } \\
\text { Umur Pengamatan (hst) }\end{array}$} & \multicolumn{4}{|c|}{$\begin{array}{c}\text { Tanpa olah tanah } \\
\text { Umur Pengamatan (hst) }\end{array}$} \\
\hline & 14 & 21 & 28 & 35 & 14 & 21 & 28 & 35 & 14 & 21 & 28 & 35 \\
\hline $\begin{array}{c}0 \mathrm{Kg} \\
\text { MULSA }\end{array}$ & $\begin{array}{c}15,2 \\
\text { tn }\end{array}$ & $\begin{array}{c}22,3 \\
\text { tn }\end{array}$ & $\begin{array}{c}30,1 \\
\text { tn }\end{array}$ & $\begin{array}{c}48,2 \\
\text { tn }\end{array}$ & $\begin{array}{c}13,5 \\
\text { tn }\end{array}$ & $\begin{array}{c}21,2 \\
\text { tn }\end{array}$ & $\begin{array}{c}26,9 \\
\operatorname{tn}\end{array}$ & $\begin{array}{c}43,0 \\
\text { tn }\end{array}$ & $\begin{array}{c}17,7 \\
\text { tn }\end{array}$ & $\begin{array}{c}24,8 \\
\text { tn }\end{array}$ & $\begin{array}{c}27,1 \\
\text { tn }\end{array}$ & $\begin{array}{c}40,2 \\
\text { tn }\end{array}$ \\
\hline $\begin{array}{c}2 \mathrm{Kg} \\
\text { MULSA }\end{array}$ & $\begin{array}{c}17,7 \\
\text { tn }\end{array}$ & $\begin{array}{c}26,2 \\
\text { tn }\end{array}$ & $\begin{array}{c}31,2 \\
\text { tn }\end{array}$ & $\begin{array}{c}42,3 \\
\text { tn }\end{array}$ & $\begin{array}{c}17,2 \\
\text { tn }\end{array}$ & $\begin{array}{c}25,1 \\
\text { tn }\end{array}$ & $\begin{array}{c}32,1 \\
\text { tn }\end{array}$ & $\begin{array}{l}46,1 \\
\text { tn }\end{array}$ & $\begin{array}{c}15,0 \\
\text { tn }\end{array}$ & $\begin{array}{l}25,5 \\
\text { tn }\end{array}$ & $\begin{array}{c}29,0 \\
\text { tn }\end{array}$ & $\begin{array}{c}41,2 \\
\text { tn }\end{array}$ \\
\hline $\begin{array}{c}4 \mathrm{Kg} \\
\text { MULSA }\end{array}$ & $\begin{array}{c}16,7 \\
\text { tn }\end{array}$ & $\begin{array}{c}26,5 \\
\text { tn }\end{array}$ & $\begin{array}{c}30,4 \\
\text { tn }\end{array}$ & $\begin{array}{c}38,1 \\
\text { tn }\end{array}$ & $\begin{array}{c}17,5 \\
\text { tn }\end{array}$ & $\begin{array}{c}25,3 \\
\text { tn }\end{array}$ & $\begin{array}{c}31,0 \\
\text { tn }\end{array}$ & $\begin{array}{c}44,2 \\
\text { tn }\end{array}$ & $\begin{array}{c}14,9 \\
\text { tn }\end{array}$ & $\begin{array}{c}24,3 \\
\text { tn }\end{array}$ & $\begin{array}{c}28,5 \\
\text { tn }\end{array}$ & $\begin{array}{c}45,5 \\
\text { tn }\end{array}$ \\
\hline $\begin{array}{c}6 \mathrm{Kg} \\
\text { MULSA }\end{array}$ & $\begin{array}{c}19,2 \\
\text { tn }\end{array}$ & $\begin{array}{c}26,0 \\
\text { tn }\end{array}$ & $\begin{array}{c}33,5 \\
\text { tn }\end{array}$ & $\begin{array}{c}44,4 \\
\text { tn }\end{array}$ & $\begin{array}{c}17,7 \\
\text { tn }\end{array}$ & $\begin{array}{c}26,1 \\
\text { tn }\end{array}$ & $\begin{array}{c}29,4 \\
\text { tn }\end{array}$ & $\begin{array}{c}40,2 \\
\text { tn }\end{array}$ & $\begin{array}{c}17,5 \\
\text { tn }\end{array}$ & $\begin{array}{c}26,9 \\
\text { tn }\end{array}$ & $\begin{array}{c}30,5 \\
\text { tn }\end{array}$ & $\begin{array}{c}43,6 \\
\text { tn }\end{array}$ \\
\hline
\end{tabular}

tn : tidak nyata dengan BNT 5\% dan tidak ada interaksi antara perlakuan olah tanah dan pemulsaan 


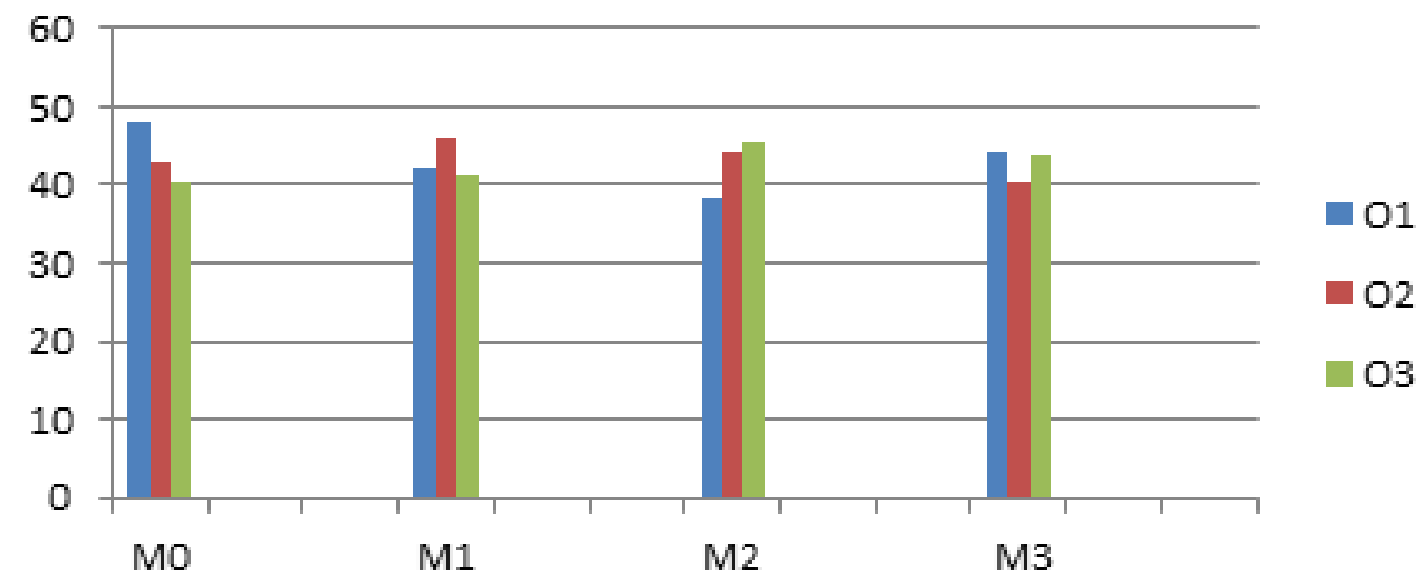

Gambar 2. Grafik tinggi tanaman kedelai pada umur 35 hst dengan berbagai perlakuan Keterangan : O1: Olah tanah sempurna, O2: Olah tanah minimum, O3: Tanpa Olah tanah, M0: Tanpa jerami padi (kontrol), M1: Jerami padi 2 ton/ha, M2: Jerami padi 4 ton/ha, M3: Jerami padi 6 ton/ha

Tabel 4. Jumlah polong tanaman kedelai pada berbagai umur tanaman dengan berbagai perlakuan $(\mathrm{cm})$

\begin{tabular}{|c|c|c|c|c|c|c|c|c|c|}
\hline \multirow[b]{3}{*}{ Pemulsaan } & \multicolumn{9}{|c|}{ OLAH TANAH } \\
\hline & \multicolumn{3}{|c|}{ Maksimal } & \multicolumn{4}{|c|}{ Minimal } & \multicolumn{2}{|c|}{ Tanpa olah tanah } \\
\hline & $\begin{array}{c}\text { Juml } \\
\text { polong }\end{array}$ & $\begin{array}{l}\text { Polong } \\
\text { Isi }\end{array}$ & $\begin{array}{c}\text { bobot } \\
\text { biji } \\
\text { pertana- } \\
\text { man }\end{array}$ & $\begin{array}{l}\text { jumlah } \\
\text { polong }\end{array}$ & $\begin{array}{l}\text { polong } \\
\text { isi }\end{array}$ & $\begin{array}{c}\text { bobot } \\
\text { pertan } \\
\text { pertana- } \\
\text { man }\end{array}$ & $\begin{array}{l}\text { jumlah } \\
\text { polong }\end{array}$ & $\begin{array}{l}\text { polong } \\
\text { isi }\end{array}$ & $\begin{array}{c}\text { bobot } \\
\text { pij1 } \\
\text { pertana- } \\
\text { man }\end{array}$ \\
\hline $\begin{array}{c}0 \mathrm{Kg} \\
\text { MULSA }\end{array}$ & $\begin{array}{c}34,7 \\
\text { tn }\end{array}$ & $27,4 \mathrm{tn}$ & $\begin{array}{r}9,7 \\
\text { tn }\end{array}$ & $\begin{array}{c}36,4 \\
\text { tn }\end{array}$ & $\begin{array}{c}28,8 \\
\text { tn }\end{array}$ & $\begin{array}{l}8,6 \\
\text { tn }\end{array}$ & $\begin{array}{c}34,8 \\
\text { tn }\end{array}$ & $26,5 \mathrm{tn}$ & $\begin{array}{l}8,2 \\
\text { tn }\end{array}$ \\
\hline $\begin{array}{c}2 \mathrm{Kg} \\
\text { MULSA }\end{array}$ & $\begin{array}{c}36,3 \\
\text { tn }\end{array}$ & $\begin{array}{c}34,5 \\
\text { tn }\end{array}$ & $\begin{array}{l}8,2 \\
\text { tn }\end{array}$ & $\begin{array}{c}35,3 \\
\text { tn }\end{array}$ & $\begin{array}{c}33,7 \\
\text { tn }\end{array}$ & $\begin{array}{l}8,9 \\
\text { th }\end{array}$ & $\begin{array}{c}37,6 \\
\text { tn }\end{array}$ & $\begin{array}{c}33,2 \\
\text { tn }\end{array}$ & $\begin{array}{l}8,7 \\
\text { tn }\end{array}$ \\
\hline $\begin{array}{c}4 \mathrm{Kg} \\
\text { MULSA }\end{array}$ & $\begin{array}{c}33,3 \\
\text { tn }\end{array}$ & $27,4 \mathrm{tn}$ & $\begin{array}{l}8,1 \\
\text { tn }\end{array}$ & $\begin{array}{c}35,7 \\
\text { tn }\end{array}$ & $\begin{array}{c}24,4 \\
\text { tn }\end{array}$ & $\begin{array}{l}8,4 \\
\text { tn }\end{array}$ & $\begin{array}{c}32,9 \\
\text { tn }\end{array}$ & $\begin{array}{c}28,4 \\
\text { tn }\end{array}$ & $\begin{array}{l}8,3 \\
\text { tn }\end{array}$ \\
\hline $\begin{array}{c}6 \mathrm{Kg} \\
\text { MULSA }\end{array}$ & $\begin{array}{c}29,4 \\
\text { tn }\end{array}$ & $\begin{array}{c}22,3 \\
\text { tn }\end{array}$ & $\begin{array}{l}7,3 \\
\text { tn }\end{array}$ & $\begin{array}{c}31,3 \\
\text { tn }\end{array}$ & $\begin{array}{c}21,3 \\
\text { tn }\end{array}$ & $\begin{array}{l}7,6 \\
\text { tn }\end{array}$ & $\begin{array}{c}38,2 \\
\text { tn }\end{array}$ & $\begin{array}{c}24,3 \\
\text { tn }\end{array}$ & $\begin{array}{l}7,7 \\
\text { tn }\end{array}$ \\
\hline
\end{tabular}

tn : tidak nyata dengan BNT 5\% dan tidak ada interaksi antara perlakuan olah tanah dan pemulsaan

Pengolahan tanah tidak berpengaruh pada pertumbuhan dan hasil tanaman kedelai. Hal ini disebabkan untuk mencapai pertumbuhan tanaman yang optimal, maka disamping keadaan tanaman secara genetik harus baik, diperlukan lingkungan yang mendukung dan sesuai dengan yang dibutuhkan tanaman selama masa pertumbuhannya. Pertumbuhan dan perkembangan tanaman ditentukan oleh faktor tanah dan iklim serta tanaman itu sendiri. Beberapa diantaranya dapat dikendalikan oleh manusia, tapi beberapa tidak demikian (Foth, 1994). Umumnya tanaman memerlukan keadaan lingkungan yang berbeda untu berbagai stadia pertumbuhan dan perkembangannya, seperti perkecambahan, pembentukan bunga, pengisian biji dan sebagainya. Pengoahan tanah yang baik dan benar sangat dibutuhkan karena mempengaruhi sifat fisik, kiia dan biologi tanah (Raintung, 2010).

Pengaruh mulsa yang belum menunjukkan perbedaan nyata pada pertumbuhan dan hasil tanaman kedelai. Hal ini dapat disebabkan oleh proses dekomposisi bahan mulsa belum sempurna. 
Mengingat waktunya yang relatif singkat, dengan demikian dapat diketahui bahwa pemberian mulsa pada perbaikan produktivitas lahan tidak langsung terlihat, akan tetapi membutuhkan waktu

yang relatif lama. (Prasetyo, et al. 2014). Kemungkinan lain ialah jumlah pemberian mulsa kurang sehingga fungsi mulsa sebagai penahan proses penguapan menjadi kurang sempurna, dimana semakin tebal mulsa maka proses penguapan yang terjadi akan semakin kecil. Selain itu juga dapat diakibatkan karena adanya hujan yang turun pada musim tanam yang dilakukan, sehingga pengaruh mulsa sebagai penahan penguapan menjadi berkurang.

Berdasarkan hasil pengamatan dapat diketahui bahwa perlakuan olah tanah dengan kombinasi pemulsaan menghasilkan pertumbuhan dan hasil tanaman kedelai yang tidak berbeda nyata, sehingga dapat sistem TOT dapat disarankan pada budidaya tanaman kedelai. Budidaya tanaman dengan sistem tanpa olah tanah (TOT) akan memiliki beberapa keuntungan untuk tanaman. Selain mengurangi evapotranspirasi, erosi, pemadatan tanah, memperkecil erosi dan pencucian unsur hara serta melestarikan kesuburan tanah, namun sistem TOT kurang optimal untuk mengendalikan gulma (Purwanto, 2010). Kelebihan lain dari cara penanaman TOT ialah mempertimbangkan aspek kelestarian sumber daya tanah dan air disamping aspek produksi dan pendapatan petani. TOT ialah suatu tindakan konservasi untuk mencegah pengaruh buruk dari system pengolahan konvensional, yaitu erosi yang menurunkan produktivitas tanah. Selain itu, sistem TOT akan menghemat biaya pengolahan tanah dan kebutuhan tenaga kerja., dan mempercepat waktu tanam sehingga akan meningkatkan penghasiln petani (Sastroutomo, 1990).

Kombinasi tanpa olah tanah dengan pemulsaan jerami padi dengan dosis 2-6 ton/ha dapat disarankan pada budidaya tanaman kedelai. Pemberian penutup tanah berupa jerami padi dapat meningkatkan kadar air tanah 17,17 \%-27,02\%, hal ini karena penutupan tanah dapat memperkecil terjadinya evaporasi dan meningkatkan absorbsi air. Penutupan tanah dengan mulsa dapat mempertahankan kelembaban tanah, karena menutup tanah merupakan usaha pengadaan bahan organik pada tanah sehingga absorbsi air meningkat, selain itu dapat memperbesar kapasitas menahan air dan memperkecil terjadinya kehilangan air (Zulfica, 1990). Peningkatan mulsa jerami padi pada tanaman kedelai akan memberikan peningkatan kandungan air tanah sehingga kebutuhan air tanaman kedelai dapat tercukupi (Radjit, 1990).

\section{KESIMPULAN}

Tidak terdapat interaksi dan pengaruh yang nyata antara perlakuan pemulsaaan dikombinasikan dengan pengolahan tanah terhadap pertumbuhan dan hasil tanaman kedelai.

\section{DAFTAR PUSTAKA}

Akbar, A. (2014). Pengaruh Mulsa Organik pada Gulma dan Tanaman Kedelai (Glycine Max L.) Var. Gema Produksi Tanaman. 1(6).

Badan Pusat Statistik (BPS)a.(2015). Pertanian dan pertambangan. http:// bps.go.id/

Badan Pusat Statistik (BPS)b. (2015). Kabupaten Ponorogo Dalam Angka. http://ponorogokab.bps.go.id/ website3502/frontend/

Foth. 1994. Dasar-dasar Ilmu Tanah. (1994). Dasar-dasar Ilmu Tanah. Erlangga. Jakarta.

Prasetyo, B.H.,. Suriadikarta, D.A. (2009). Karakteristik, Potensi dan Teknologi Pengolahan Tanah Ultisol untuk Pengembangan Pertanian Lahan Kering di Indonesia. ht tp://www. pustaka-deptan.go.id

Prasetyo, Rizky Adie., Agung Nugroho dan Jody Moenandir. (2014). Pengaruh sistem olah tanah dan berbagai mulsa organik pada pertumbuhan dan hasil tanaman kedelai (Glycine max (L.) Merr.) Var. Grobogan. Jurnal 
Produksi Tanaman 1(6).

Purwanto, (2010). Kajian Fisiologi

Tanaman Kedelai Pada Kondisi Cekaman Kekeringan dan Berbagai

Kepadatan Gulma Teki. Agrosains 12(1): 24-28

Radjit, B. S. (1991). Kajian penggunaan mulsa, pengolahan tanah dan pengairan terhadap pertumbuhan serta hasil kacang hijau di tanah regosol. dalam risalah hasil penelitian tanaman pangan. Balittan Malang

Raintung. (2010). Pengolahan Tanah dan Hasil Kedelai. Jurnal Soil Environtment. 8(2) : 65-68

Sastroutomo, S.S. (1990). Ekologi Gulma. PT. Gramedia Pustaka Utama, Jakarta.

Zulvica. (1990). Pengaruh penutup tanah terhadap pertumbuhan dan hasil kedelai. Skripsi. Fakultas Pertanian Universitas Sriwijaya. Palembang. 